\title{
Tough Love: The True Nature of the Eurozone Crisis
}

\author{
HOLGER SCHMIEDING*
}

There are a number of misconceptions about the ongoing Eurozone crisis. One is that it is a debt crisis: in fact many countries that are considered to be reasonably sound have bigger long-term fiscal deficit problems than even the weakest Eurozone countries. The crisis partly reflects the pain of frontloaded fiscal repair. But even more so, the crisis has turned into a step-by-step attempt to forge a stronger and more coherent Europe. The reluctance of the European Central Bank to defuse the tensions which this process creates makes the region vulnerable to bouts of market turmoil. This paper outlines the course of the crisis, the policy responses to date, and the actions that are necessary to resolve it.

Business Economics (2012) 47, 177-189.

doi:10.1057/be.2012.17

Keywords: Eurozone, banking crisis, Greece, European Central Bank, sovereign debt, contagion

$\mathrm{H}$ ardly any region of the world has had a worse press in the last 30 months than the community of 17 European countries that share a common currency, the euro. Judging by the tone of the global debate, the Eurozone must be a uniquely dysfunctional place, run by policymakers "who just don't get it". While the euro crisis is dangerous and very much for real, much of the global debate seems to miss the key points. We are not witnessing the inevitable demise of a misguided venture - a common currency - as many observers seem to believe. Instead, we may be witnessing the birth pains of a stronger, more dynamic, and more coherent economic and political entity in Europe. The attempt to create a stronger Europe could still go wrong, but we should at least acknowledge it for what it is.

Starting initially as a Greek public debt problem at the end of 2009, the euro crisis has turned over the course of 2011 into an attempt by Northern European euro members to change the rules of the game in a way that prevents any recurrence of such troubles in the future. The four key features are:

1. Northern members of the Eurozone, led by Germany and supported by the European Central Bank (ECB), are trying to impose a new set of fiscal rules as well as some major pro-growth structural reforms onto the southern members of the 17-nation club.

2. This drive for new rules and reforms carries an implicit promise: all countries that sign up to and respect the new rules will be defended against market turmoil and kept in the common currency, if need be by putting huge amounts of taxpayer money from Northern Europe as well as the central bank balance sheet at risk.

3. It also comes with a threat: any country that breaks the rules does so at its own risk. Greece would probably be cut off from European support funds if it votes against the bailout terms on offer. It would then have to print its own currency, as euros would run out shortly after Northern Europe switches off the life support system. Ireland would not have qualified for any follow-up assistance from Europe had it not ratified the new European fiscal pact in its referendum on May 31.

4. The way in which the new rules will be applied has not been cast in stone. The rules will probably be

Based on an address delivered to NABE's Annual Washington Economic Policy Conference, March 26, 2012.

*Holger Schmieding is chief economist of Berenberg Bank. Previously, he was Managing Director and Head of European Economics at Bank of America Securities-Merrill Lynch in London. He worked as Senior Strategist and Chief Economist for Continental Europe at Merrill Lynch in Frankfurt (1994-1997) and London (1998-2001), as Senior Economist at the International Monetary Fund in Washington, DC (1993) and as Assistant to the President and Head of the Research Group on Transformation Countries at the Kiel Institute of World Economics (1986-1992). Schmieding holds a doctorate in economics from Kiel University and has published three books and a number of articles about German economic history, European economic integration, and the transformation process of post-social economies in Europe. He has written regular columns for German FAZ, Newsweek International, and other publications. 
handled more flexibly than their lead architect, German chancellor Angela Merkel, had originally planned. The extra flexibility on details - but not on principles - comes in response to some political backlash against excessive austerity, visible for instance in the French presidential elections as well as in some German regional polls.

\section{Debt Crisis?}

The Eurozone crisis is often portrayed as a debt crisis. Like many popular misconceptions, this portrayal contains one or two kernels of truth: tiny Greece and two even smaller countries (Portugal and Ireland) are struggling with serious public debt crises. In addition, the outlook for public finances plays a major role in the Eurozone discussions. But the "debt crisis" label misses the major story.

As Table 1 shows, the United States carries a greater public debt burden than the Eurozone, and the United Kingdom comes close to the Eurozone ratio of gross public debt to GDP. In fact, the United Kingdom looks set to surpass the Eurozone's debt ratio by 2013 at the latest.

The point comes out even more clearly if we look at the running fiscal deficit rather than the accumulated stock of gross public debt. In 2011, the fiscal deficit of general government in the Eurozone (4.1 percent of GDP) was far below that of the United Kingdom (8.3 percent) and the United States (around 10 percent). Relative to the United States and the United Kingdom, the Eurozone needs only comparatively minor adjustments to put its public finances on a sustainable path.

A calculation by the International Monetary Fund [2012] underscores this point. Figure 1 shows that in order to reduce general government gross debt to 60 percent of GDP by 2030 and cope with the burden of an aging population, Japan would have to tighten its fiscal policy by a cumulative 18.9 percent of its GDP until 2020, the United States by 17.6 percent, and the United Kingdom by 11.3 percent. This exceeds the tightening need in Germany ( 2.5 percent), Italy (3.6 percent), Ireland (5.3 percent), France (6.6 percent), and Spain (10 percent) by a wide margin. Even Greece (10.7 percent) has less hard fiscal work left to do than the United States, the United Kingdom, and Japan on these IMF calculations.

This leads us to the fiscal paradox of Europe: although the Eurozone as a whole has much less need to tighten its fiscal policy than all other major regions of the Western world, most Eurozone countries are now delivering their still-required

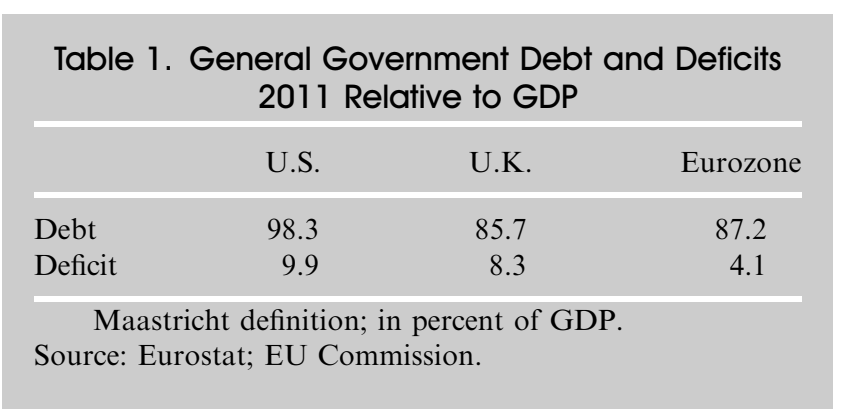

Figure 1. Tightening Need, Adjusted for Age-Related Spending

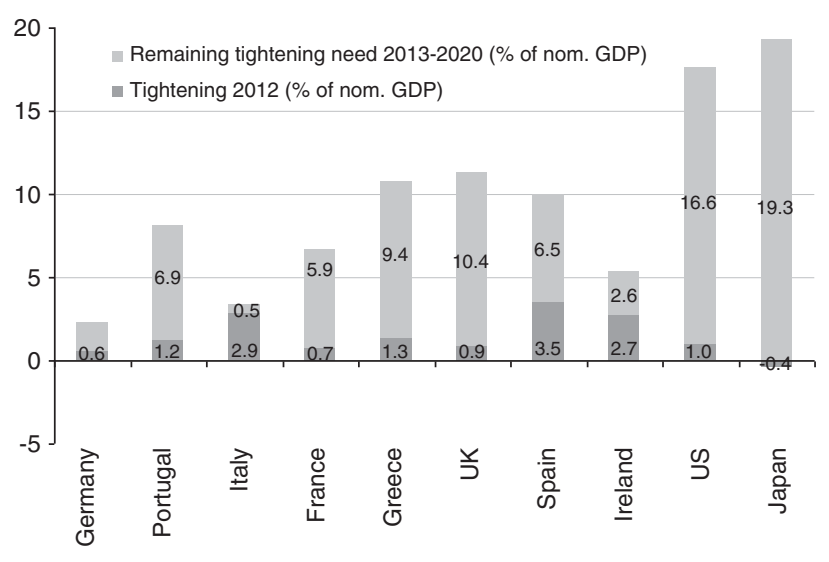

Source: IMF Fiscal Monitor April 2012.

fiscal repair in a very frontloaded manner. Take the most striking example: According to the IMF Fiscal Monitor [2012], Italy is implementing almost the entire fiscal repair required in the long term in one single year, namely 2012. Of a cumulative need to correct its fiscal stance by 3.4 percent of its GDP until 2020 to reach the benchmark (60 percent debtto-GDP ratio by 2030), Italy has imposed spending cuts and tax hikes worth 2.9 percent of its GDP in 2012. At the same time, those countries with the biggest need to adjust (Japan and the United States) have barely started the effort.

To understand the underlying dynamics in Europe in responding to the debt and deficit situation, we first need to discuss some basic features of the euro crisis and the Eurozone.

\section{Two distinct phases of the crisis}

The Greek crisis erupted in late 2009 when, shortly after a national election, the new Greek government revealed that the old government had de facto lied about the extent of the fiscal deficit. As the Greek 
fiscal deficit for 2009 was revised up and up from a preelection forecast of "around 7 percent" of GDP until it surpassed 15 percent of GDP, global investors refused to buy Greek sovereign bonds, forcing Greece to ask for help from the other 16 Eurozone member countries and the International Monetary Fund in April 2010. Although Ireland and Portugal had to follow suit in late 2010 and early 2011, the problems of these three peripheral countries did not hold back the overall Eurozone economy by much. Taken together, Greece, Ireland, and Portugal account for a mere 6 percent of Eurozone GDP. Despite serious problems in these very small countries, the overall Eurozone was the only economic region in the Western world that enjoyed trend growth in the first half of 2011.

But in mid-2011, the Eurozone economy suddenly decoupled from the rest of the world. Figure 2 shows the sudden divergence in the Purchasing Managers Index for manufacturing for the Eurozone and a weighted average for the United States and China, the other two global heavyweights. Having avoided any serious contagion from the debt crisis in some small peripheral economies to the Eurozone as a whole until then, contagion suddenly spread like wildfire in the summer and autumn of 2011. Whereas the U.S. economy regained some momentum in late 2011 and early 2012 and China enjoyed a soft landing, the Eurozone contracted in 2011:Q4 and stagnated in 2012:Q1. The key issue in the Eurozone crisis has never been the fate of Greece or some other small highly indebted country. The key issue has always been contagion control. Greece, Ireland, and Portugal have genuine debt crises. The Eurozone as a whole does not. The Eurozone economy only hit the rocks when contagion control failed in July 2011.

Figure 2. PMl: the United States and China vs. Eurozone

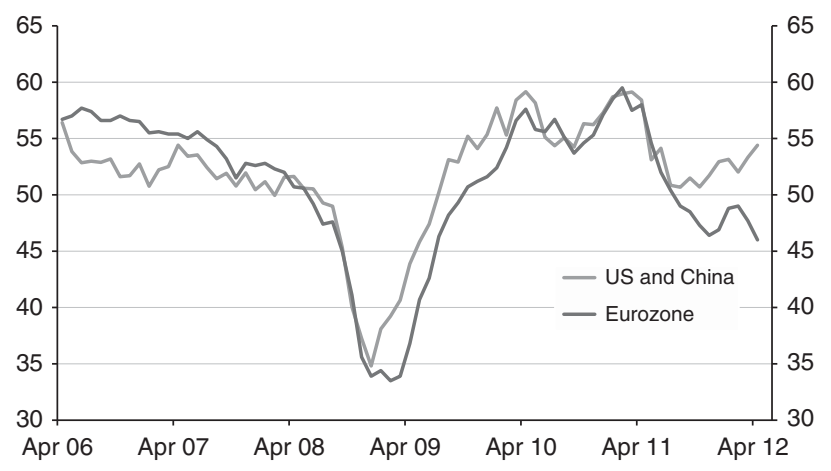

Source: Markit.
To some extent, the frontloaded and severe austerity in parts of the Eurozone contributes to the gap between the Eurozone and other major economies. But it is not the main factor.

\section{Two aspects of financial crisis: The problem and the panic}

As a first step to understand the true nature of the Eurozone crisis, we need to clearly distinguish between two different aspects of a financial crisis.

1. The underlying problem, say an asset bubble that has turned to bust or an over-indebted sovereign that has lost access to markets.

2. The financial panic that can be triggered by such an underlying problem.

The distinction is similar to the two risks which arise if somebody cries "fire" in a crowded theatre. There may actually be a dangerous fire. But in a panic rush to escape from a fire, whether real or imagined, people may also trample each other to death. The second risk exists whether or not the alarm later turns out to have been a real or a false one.

The U.S. experience illustrates the distinction between these two aspects of a financial crisis. From mid-2007 onward, the United States had a serious fundamental problem. One of the worst real estate bubbles ever, the Greenspan bubble, was going bust. This was bound to cause major strains in the U.S. financial system with losses of several hundred billion dollars. When Bear Stearns became insolvent in March 2008, the issue was handled well. The U.S. economy stayed in a rather mild recession, and the rest of the world barely wobbled. But when the United States grossly mismanaged the insolvency of Lehman Brothers in September 2008 , de facto shutting down major parts of the global wholesale financial markets instead of winding down the firm in an orderly manner, the ensuing financial tremors pushed the Western world into its worst recession in 80 years. That German GDP nosedived by 6.2 percent within the two quarters after Lehman had nothing to do with direct or indirect exposure to U.S. real estate. It was the result of a panic that the U.S. authorities had allowed to erupt and spread. Only when the U.S. Federal Reserve signalled that it would do virtually everything to stop the rot, including almost unlimited purchases of U.S. securities, did the panic end. One month after the Federal Reserve leaked to the press in early March 2009 that it 
was discussing "quantitative easing", the German economy went straight back from mega-recession to a rapid pace of growth.

No central bank can correct underlying fiscal problems or structural deficiencies in a labour market. But a central bank can prevent or arrest the financial panic that may erupt if such an underlying problem is mishandled. In the United States, the United Kingdom, and Japan, the central banks are ready to buy assets in abundance in order to calm markets, lower sovereign borrowing costs, and/or pump in extra liquidity into the dysfunctional parts of the financial system. They respond eagerly to any real or perceived risk of a panic. In the Eurozone, the ECB holds back.

\section{Unique Features of the Eurozone}

\section{The central bank response function}

The most startling difference between the Eurozone on the one hand and the United States and the United Kingdom on the other hand is the reaction function of the central bank to financial turmoil and economic problems. Figure 3 shows the amount of central bank asset purchases since the onset of the Lehman crisis as a share of the respective region's GDP. Whereas the Federal Reserve and the Bank of England (BoE) have been extremely active, the ECB has intervened far less.

In response to the Greek crisis and the risks of contagion from Greece to the Eurozone as a whole, the 17 countries sharing the euro have erected various firewalls. If the European Stability Mechanism (ESM) gets ratified, the total size of the firewalls of the European Financial Stability Facility (EFSF) and ESM would reach $€ 750$ billion, including the resources already committed to the support programmes for Greece, Portugal, and Ireland. With a potential maximum contribution by the International Monetary Fund of, say, $€ 200$ billion, the overall sum is quite sizable. But it is dwarfed by the amounts that the Federal Reserve and - relative to British GDP - the BoE have spent on asset purchases. If the ECB had bought assets as freely as the Federal Reserve and the BoE, it would have bought an $€ 1.4$ trillion or $€ 1.6$ trillion, respectively, more in sovereign or mortgage bonds than it actually has. Put differently: The Eurozone only needs such fiscal firewalls to protect itself against financial turmoil because the ECB refuses to provide the firewall itself.

All it would take for the financial turmoil to end in Europe would be a clear announcement by the
Figure 3. Central Bank Asset Purchases (In percent of GDP). Actual and announced since 2008:Q4

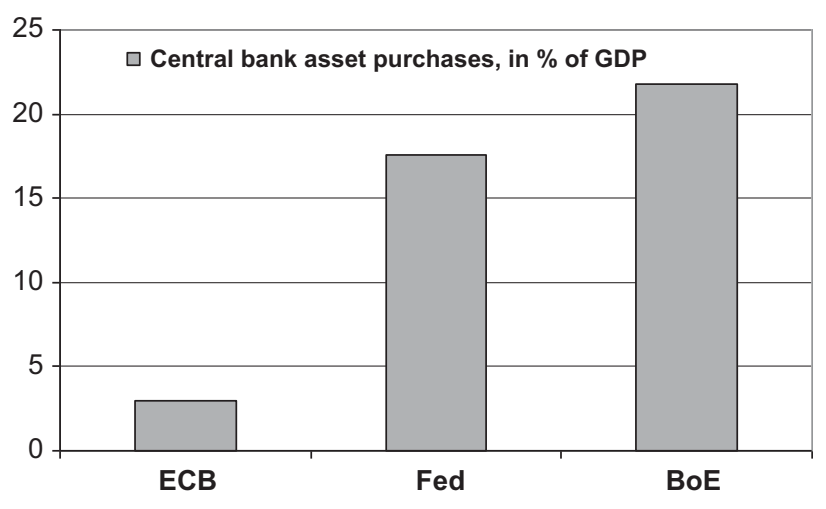

Source: ECB; Eurostat; Berenberg projections.

ECB that it would forthwith act as a lender of last resort, just as the Federal Reserve, the BoE, and the Bank of Japan do. Of course, such an ECB intervention would not solve the real estate problems of Spain and Ireland and would not spare some Eurozone members the pain of having to correct their fiscal stance over time. But it would end the financial tremors currently haunting the region.

Why does the ECB not react to financial turmoil and recession risks like other central banks? The ECB is a unique institution. Superficially, it differs from the Federal Reserve in that the ECB has the sole mandate of safeguarding price stability, not a dual price stability/full employment mandate. In practice, the exact mandate probably does not matter much, though. In its discussions of future risks to price stability, the ECB takes full account of labour markets trends and output gaps.

Instead, the defining feature of the ECB is that it is the most independent central bank in the world, for three reasons which are closely related:

1. The ECB does not face one finance minister. Instead, it interacts with a disparate group of 17 national finance ministers, who rarely agree. The ECB can afford to pretty much ignore any of them. In the Eurozone, the central bank president cannot meet the finance minister for U.S.style cosy breakfasts because there is no such finance minister for the Eurozone as a whole.

2. In the United States, it would take one act of Congress, and in the United Kingdom one act of parliament, to change the mandate or setup of the central bank. In the Eurozone, no politician can credibly threaten implicitly or explicitly to 
change the mandate of the central bank or the process by which board members are selected if he disagrees with the course of monetary policy. Any change to the ECB mandate would have to be ratified by all European Union member states, in some cases by referendum. That is close to impossible, about as difficult as inserting, say, a binding balanced-budget amendment into the U.S. constitution - especially if such an amendment would hypothetically have to be ratified by all and not just most U.S. states.

3. The ECB largely sees itself as the heir to "best practice" monetary policy in Europe, which is the traditionally hard-nosed Bundesbank approach.

\section{Horizontal transfers: The tough-love approach}

Not only is the ECB by design a much more independent and hard-nosed creature than national central banks elsewhere. In a similar vein, the unique institutional set up of the multination Eurozone systematically favours a tough-love approach to internal problems.

The Eurozone is neither one nation nor a bunch of separate nations who care little about each other. The Eurozone is kept together by strong political glue - the lessons Germany, France, and other nations have drawn from the two disastrous wars in which much of the continent destroyed itself in the first half of the 20th century. Helped also by a protective U.S. military umbrella, the European integration that started with the European Coal and Steel Community in 1951 has delivered the longest period of peace and prosperity which Europe has enjoyed in almost 2000 years.

The Eurozone is best understood as a family, separate individuals kept together by strong longterms bonds which, of course, are not unbreakable.

As in a family, or in groups of individuals allowed to cooperate in potentially infinite repeated games, there is a basic solidarity between members. But the transfers are largely horizontal, from member to member, rather than vertical from a strong centre to subordinate parts of a nation. The donors can and do set the terms at which they grant support to the recipients. Put simply: Germany (as a donor) can be much tougher on Spain (as a recipient) because Spaniards do not vote in the national election that counts for the government setting the conditions, the German election. The U.S. sunbelt (or Greater London) as a donor could never be similarly tough on the U.S. rustbelt (or on
Greater Glasgow) as Germany can be on Greece or Spain. Within nation states such as the United States and the United Kingdom, the recipients vote in the relevant national elections; within the Eurozone, they do not.

As a result, the support that Eurozone countries grant each other mostly takes the form of highly conditional credits rather than nonrefundable transfers. For this reason, there is much less risk of moral hazard in the mutual support system between Eurozone countries than in the usual transfer systems within nation-states.

On static criteria of an optimum currency area, the lack of major automatic and unconditional transfers within member countries counts against the Eurozone. But on the more important dynamic criterion as to whether the institutional setting of the Eurozone is incentive-compatible, this counts as an advantage: those who need support can only get it if they accept conditions for fiscal repair and for supply-side reforms that will make their economies more dynamic and hence less likely to require aid in the future.

The tough-love nature of the Eurozone's support system explains why peripheral Eurozone members are now correcting their fiscal imbalances in such a front-loaded way. But the hard-nosed institutional set up of the Eurozone also has one major drawback: donors who can dictate conditions to the recipients may not always get it right. The conditions can be too tough. That is the essence of the Greek tragedy (see the discussion of the Greek adjustment experience in the Appendix).

\section{The risk-free asset?}

Modern financial systems are built around a riskfree asset. In mature economies, many financial products are priced relative to the domestic sovereign yield curve. Holdings of sovereign bonds are a key part of bank assets and a cornerstone of insurance strategies and pension plans. Even institutions that do not hold large amounts of these assets themselves base their investment strategies explicitly or implicitly on the sovereign yield curve as the benchmark.

Of course, sovereign bonds are never fully "risk-free". Even the very short-end of the sovereign curve, which is usually highly liquid and subject only to limited interest rate risk, carries foreign exchange risk for foreigners and the risk that real returns can be eroded by inflation for domestic investors. But the nominal value of the principal 
held to maturity is usually safe. If need be, the sovereign can print the money to service its nominal debt.

By giving up their own currencies in favour of the euro, Eurozone members lost their traditional risk-free asset. They no longer have a national central bank that could, if need be, print the domestic currency to continue servicing the sovereign debt denominated in the domestic currency. For domestic investors, domestic sovereign bonds denominated in the new domestic currency, the euro, now carry a genuine credit risk.

The switch from national currencies to the euro enabled a major convergence of sovereign bond yields across the Eurozone. But it also made the financial systems of member states more vulnerable to any problems in their domestic sovereign bond markets. Note that, in the bank-based financial system of the Eurozone, the risk-free asset - or the lack of it - arguably plays a more important role than in the United States with its more capitalmarkets based system of financial intermediation.

\section{The Course of the Crisis}

Having discussed the main features of the Eurozone, we can now take a closer look at the evolution of the euro crisis. Following the Greek request for help in April 2010, Eurozone financial markets started to seize up. Immediately after an ECB "business as usual" press conference on May 6, 2011, the turbulence escalated to such a degree that - afraid of being on the verge of a Eurozone equivalent of the Lehman contagion disasterEurozone policymakers hastily erected a $€ 500$ billion firewall against contagion risks and asked the International Monetary Fund to pledge a further $€ 250$ billion. Breaching a long-held taboo, the ECB started to buy some Greek sovereign bonds on the secondary market.

The attempt to contain contagion was highly successful for more than a year. Although Ireland and Portugal had to ask for help in late 2010 and early 2011 respectively, Figure 4 shows that the Eurozone economy as a whole continued to strengthen until mid-2011, with the EU Commission's economic sentiment index advancing from 94.1 in December 2009 to a peak of 107.6 in February 2011 before slipping marginally to 104.9 in June 2011, well above the 100 historic average. By mid-2011, that is more than 18 months after the onset of the Greek crisis, the biggest country within the Eurozone, Germany, was approaching
Figure 4. Eurozone business and consumer confidence (July 2011: Greek default decision)

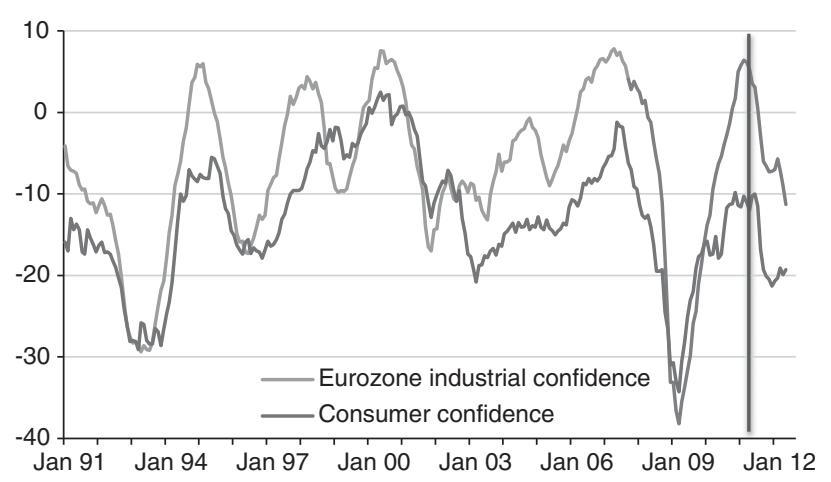

an economic boom. The ECB, which had long ceased to buy Greek as well as Irish and Portuguese bonds, even raised interest rates in April and July 2011.

The only fly in the ointment was that the Greek adjustment programme was not delivering the envisaged result. In a deepening Greek recession, the chances that Greece would be able to return to capital markets as planned in mid-2012 were fading.

Two developments brought the Greek issue to a head:

1. The International Monetary Fund, temporarily led by an American official after the exit of its French managing director Strauss-Kahn, insisted that it could no longer disburse a further tranche of its support for Greece unless the follow-up financing for Greece beyond mid2012 was agreed immediately, that is one year in advance of the expiry of the first EU/IMF programme.

2. The German finance minister insisted that private sector holders of Greek sovereign bonds ought to "contribute" to any second support programme for Greece. In other words, he argued for a sovereign default.

With the start of an official discussion about a Greek default in late June 2011, yields spreads for Italian and Spanish sovereign bonds over German Bunds started to widen significantly. Although the ECB and the German Bundesbank warned loudly and clearly that a Greek sovereign default could spark major turmoil, an EU summit on July 21, 2011 decided to pursue a "voluntary" restructuring 
of Greek sovereign debt held by non-official creditors. Following escalating turmoil in Eurozone bond markets, equity markets plunged in August and September 2011. The Eurozone economy went straight from trend growth in the first half of 2011 into a contraction of GDP in Q4 of the same year. Europe had allowed contagion to spread.

The first mistake was to break Europe's previous promise to fully repay Greek sovereign debt as long as Greece subjected itself to an austerity and reform programme. This cast doubt of the status of the "risk free benchmark assets" in all countries on the Eurozone periphery. The bigger mistake was to do so without first erecting adequate safeguards against the risk of contagion to Italy. Whereas the funds available from the first firewall would have sufficed to reliably protect Spain, they were insufficient to reliably keep the biggest single sovereign debt market in Europe, Italy, out of harm's way.

Although the ECB finally started to buy sovereign bonds again in August 2011, it did so rather half-heartedly. The impression at the ECB that Italian Prime Minister Berlusconi was not implementing all the fiscal and structural reforms that the ECB had seen as a precondition for its direct intervention in the Italian sovereign bond market added to the reluctance of the ECB to play the lead role in containing contagion.

\section{Banking crisis: The law of unforeseen consequences}

A mishandling of the banking crisis exacerbated the stress in European sovereign bond markets. Heeding advice from the IMF and a long list of mostly American and British observers, European banks were subjected to a stress test and were asked to raise their capital buffers against potential losses from their holdings of sovereign bonds of peripheral Eurozone countries.

At first glance, the logic behind the stress tests is convincing: in a financial crisis, one of the top priorities must be to shore up the banking system. If banks hold dodgy assets, they need to acknowledge the losses and be recapitalised as fast as possible in order to avoid a general credit crunch. This logic makes perfect sense after the bursting of a real estate bubble such as in the United States and the United Kingdom. There are losses that need to be dealt with. Within the Eurozone, it also applies to Ireland and Spain, which both have to clear away the financial debris left behind by the bursting of a real estate bubble. But for the sovereign debt issues in the Eurozone, the "write down and recapitalise" approach turned into a major catalyst of contagion.

Take the case of Italy, the biggest single sovereign bond market in the Eurozone. As discussed above, Italy's fiscal position is much more sustainable than that of the United States, the United Kingdom, or Japan. When Europe decided to restructure Greek debt, investors started to worry whether this may happen to them in Italy as well. The key task for policymakers should have been to reassure markets that Italian debt is safe. Instead, regulators asked banks in the stress test exercise to treat Italian sovereign debt as toxic and set aside extra capital to cover the perceived risks. As a result, banks held back from buying Italian sovereign bonds. This, in turn, exacerbated the crisis and depressed prices for Italy's bonds even further, making bank holdings of such bonds look even more toxic. The quasi buyers' strike against Italian sovereign debt was one of the major transmission mechanisms of contagion from small Greece to the much bigger Italian economy and the Eurozone as a whole. With an 18 percent share of Eurozone GDP, Italy matters thrice as much as Greece, Ireland, and Portugal combined.

Banks stand to lose major amounts of money if a real estate bubble bursts. But in the Eurozone crisis, the key task is not to deal with inevitable losses but to prevent the emergence of such losses in the first place. If contagion control succeeds, Italy will be able to fully service and repay its sovereign bonds because its underlying fiscal position is comparatively sound. But an irrational panic, a buyers' strike, can potentially bankrupt even a solvent country.

By November 2011, the Eurozone crisis had escalated to such an extent that even the hardnosed ECB - and the hardcore Bundesbankers within the ECB - were getting concerned. On the one hand, they are ready to tolerate significant economic and financial stress, as such stress gives politicians a strong reason to fortify their economies through fiscal repair and structural reforms: the ECB does not see itself as an institution that, by intervening early and massively, helps policymakers to postpone hard fiscal and reform decisions. On the other hand, the ECB and the Bundesbank do not want to put the existence of the Eurozone at risk either.

In reaction to escalating turmoil, both the Bundesbank and the ECB changed tack in early 
December. The Bundesbank offered money for a bigger safety net to support Italy, disguised as a German $€ 45$ billion contribution to IMF resources. The ECB announced a massive injection of liquidity into the banking system in the form of two three-year refinancing operations at extremely favourable conditions for banks. Net of the expiry of other ECB refi operations, the ECB added some $€ 500$ billion to the liquidity buffers of banks in late December 2011 and early March 2012. Many banks in Spain and Italy used part of these funds to buy domestic sovereign bonds, pocketing the difference between their 1 percent funding costs at the ECB and sovereign bond yields around 6 percent. Thus, the Eurozone crisis eased considerably in the first two months of 2012.

Led by a resurgent Germany, the Eurozone economy temporarily stabilised in 2012:Q1. However, Bundesbank demands for an ECB "exit strategy" in early March 2012, news of a significant overshoot in Spain's 2011 fiscal deficit (8.9 percent instead of the planned 6 percent), and an inconclusive Greek election on May 6 triggered a major new wave of the euro crisis. The wave was still gathering force at the time of writing in late May 2012.

\section{The Changing Nature of the Crisis}

Crises are not just periods of noisy turmoil and heightened risks. They can also be handmaidens of change. In the Eurozone, the change in policies is clearly visible:

1. Many Eurozone member countries are implementing a series of structural reforms, including a comprehensive labour market reform in Spain, as shown in Table 2.

2. On the Eurozone level, leaders are reforming the governance of the region. They key project is a new "fiscal pact", endorsed by 25 of the 27 EU members. The pact commits countries to reduce their cyclically adjusted fiscal deficits to no more than 0.5 percent of their GDP on a prescribed schedule. De facto, this is the European version of a "balanced budget amendment" to the U.S. constitution.

The spread of contagion from small Greece to big Italy and the Eurozone as a whole in late summer 2011 was an accident. As a result, both Germany and the ECB found themselves in a position they had not sought, namely as the ultimate guarantors of the Eurozone amid massive market turmoil and a gathering global discussion about a possible collapse of the Eurozone. Without Germany, which accounts for 27 percent of Eurozone GDP and is the only major euro member which still enjoys a AAA rating from the three big bond rating agencies, no attempt to shore up Eurozone countries in trouble would be credible; without the ECB and its power to create and inject liquidity into the banking system and potentially buy sovereign bonds, attempts to prevent or stop a market panic may not succeed.

For Germany and the ECB, letting the Eurozone falter was never an option. The self-interest of the ECB dictates that it has to preserve a Eurozone since without a common currency it would cease to exist. And for Germany, promoting European integration is the key lesson that the country has drawn from the World Wars of the first half of the 20th century. So far, the German parliament endorsed all requests to put more German taxpayer money at stake in Eurozone firewalls with majorities of roughly 85 percent.

But simply intervening without imposing new conditions is not palatable to Germany and the ECB. As a quid pro quo for providing more support, Germany and the ECB in the autumn of 2011 demanded a stricter fiscal constitution for the Eurozone. While such a new fiscal constitution may not on its own end the current crisis, it would reduce the risk of a repeat fiscal crisis in the future.

The advent of new reform-minded governments in Italy and Spain in late 2011 and the agreement of all euro members (and almost all other EU members except the United Kingdom) on a stricter fiscal straightjacket for the Eurozone at an EU summit on December 8-9, 2011 were the basis for the ECB offer of two three-year, long-term refinancing operations and for the Bundesbank offer of some $€ 45$ billion to increase the general resources of the IMF, as discussed above.

More than anything else, this showed that the policy response to the euro crisis has clearly moved on from an initial attempt to prevent contagion to an attempt to thoroughly overhaul the governance structure of the region.

\section{Outlook}

The euro crisis is still unfolding. The Eurozone defences against contagion could soon be tested to the limit by a potential Greek euro exit if Greek voters decide that they do not want to accept the harsh conditions they have to meet to qualify for support. 


\begin{tabular}{|c|c|c|c|c|c|}
\hline & Unemployment Benefit Cuts & $\begin{array}{l}\text { Easing Work Force } \\
\text { Adjustment }\end{array}$ & $\begin{array}{l}\text { Making Collective } \\
\text { Bargaining Flexible }\end{array}$ & Wages/Pay & Other \\
\hline $\begin{array}{l}\text { Germany } \\
2003-05\end{array}$ & $\begin{array}{l}\text { Duration reduced from } \\
\text { max. } 2.5 \text { to } 1 \text { year } \\
\text { Benefits lost if job } \\
\text { offer not accepted }\end{array}$ & $\begin{array}{l}\text { Temp agency rules } \\
\text { liberalised to loosen } \\
\text { dismissal protection. } \\
\text { - Rules also eased for } \\
\text { small firms. }\end{array}$ & $\begin{array}{l}\text { Threat of "opening } \\
\text { clauses" forced unions } \\
\text { to allow flexibility, } \\
\text { especially on working } \\
\text { hours. }\end{array}$ & $\begin{array}{l}\text { No direct legislation } \\
\text { either. But high } \\
\text { unemployment forced } \\
\text { unions to accept wage } \\
\text { moderation. }\end{array}$ & $\begin{array}{l}\text { Employment agency } \\
\text { reform } \\
\text { - Incentives for } \\
\text { self-employment } \\
\text { Control SSC (health, } \\
\text { pension) }\end{array}$ \\
\hline $\begin{array}{l}\text { Greece } \\
2009-12\end{array}$ & & $\begin{array}{l}\text { - Severance pay cut } \\
\text { - Flexible employment } \\
\text { forms } \\
\text { - End of "unilateral"“ } \\
\text { arbitration }\end{array}$ & $\begin{array}{l}\text { End of automatic } \\
\text { extension } \\
\text { - Max. duration } 3 \text { years } \\
\text { - Firm-level prevail over } \\
\text { sectoral deals }\end{array}$ & $\begin{array}{l}\text { Minimum wage } \\
\text { reduced by } 22 \text { percent }\end{array}$ & $\begin{array}{l}\text { - Wage freezes } \\
\text { - Liberalisation of closed } \\
\text { professions }\end{array}$ \\
\hline $\begin{array}{l}\text { Portugal } \\
2011-12\end{array}$ & $\begin{array}{l}\text { Reduced generosity and } \\
\text { duration (Max. duration } \\
\text { cut from } 15 \text { to } \\
12 \text { months) }\end{array}$ & $\begin{array}{l}\text { - Reduced severance } \\
\text { pay (to EU average) } \\
\text { Eased individual } \\
\text { dismissal }\end{array}$ & - Some decentralisation & $\begin{array}{l}\text { - Overtime pay halved } \\
7 \text { days } \\
\text { - Minimum wage frozen } \\
\text { (was } 50 \text { percent below } \\
\text { GR) }\end{array}$ & $\begin{array}{l}\text { - Working time reduction } \\
\text { in crises (similar German } \\
\text { "Kurzarbeit") }\end{array}$ \\
\hline $\begin{array}{l}\text { Spain } \\
2011-12\end{array}$ & $\begin{array}{l}\text { Means-tested UE } \\
\text { benefit (with } \\
\text { incentive to accept } \\
\text { capitalisation) }\end{array}$ & $\begin{array}{l}\text { Reduced max. } \\
\text { severance }(44 \text { days } \\
\text { per year-33/20 days) })^{1} \\
\text { - } \begin{array}{l}\text { Limitation to temporary } \\
\text { contracts (2 years) }\end{array} \\
\text { - Automatic } \\
\text { reinstatement } \\
\text { restricted (art. } 18 \text { labour } \\
\text { statute })^{2}\end{array}$ & $\begin{array}{l}\text { - Companies can opt out } \\
\text { of collective } \\
\text { bargaining } \\
\text { - End of automatic } \\
\text { extension }\end{array}$ & & $\begin{array}{l}\text { SSC incentive for } \\
\text { hiring young people } \\
\text { - Self-employment } \\
\text { incentives } \\
\text { Employment agency } \\
\text { resources boost } \\
\text { - Incentives to hire } \\
\text { young people } \\
\text { - Incentives for } \\
\text { self-employment } \\
\text { - Liberalisaton of } \\
\text { closed professions }\end{array}$ \\
\hline
\end{tabular}


Mounting problems in the Spanish banking sector could also cause significant market concern. In addition, the fiscal pact still needs to be ratified.

But chances are that Northern Europe, led by Germany, and the ECB will manage to contain the crisis once again, as they had done in May 2010 and December 2011. Both have sent a clear message to all Eurozone members: as the price for support in the current crisis, we need a set of rules that will prevent the emergence of similar crises in the future. If you sign up to the rules, we will support you through temporary adjustment difficulties. Support will not come at the first hints of trouble, as would be the case in the United States and the United Kingdom. Support will only be granted as a last resort, but it will be granted, if need be.

This drive for new rules and reforms carries an implicit promise: all countries that sign up to and respect the new rules will be defended against market turmoil and kept in the common currency, if need be by putting huge amounts of taxpayer money from Northern Europe as well as the ECB balance sheet at risk. It also comes with a threat: any country that breaks the rules does so at its own risk.

To assess the future outlook for the Eurozone, we have to move beyond the focus on the actual crisis and the policy response. The crisis would not have happened if serious economic imbalances within the Eurozone had not made the region vulnerable to financial turmoil.

Under the impact of the crisis and the policy responses to the crisis, these economic imbalances within the Eurozone are now diminishing rapidly. All countries at the Eurozone periphery have raised their exports fast in the last few years. In one of the most startling adjustments, Spain has turned a deficit in its net exports of 7 percent of GDP in early 2008 into a small surplus by late 2011, as shown in Figure 5. In addition, a wave of structural reforms is sweeping through most countries on the Eurozone periphery. ${ }^{1}$ As a result, the Eurozone that will eventually emerge from the current painful period of front-loaded austerity and structural reforms is likely to be a more flexible, coherent, and dynamic place than before.

The future Eurozone will be neither a nationstate nor a full fiscal union with largely harmonised tax and spending policies and huge automatic transfers between regions. But it will be a region

\footnotetext{
${ }^{1}$ See for instance Schmieding and others [2011].
}

Figure 5. Spanish net exports. Real net exports, GDP definition

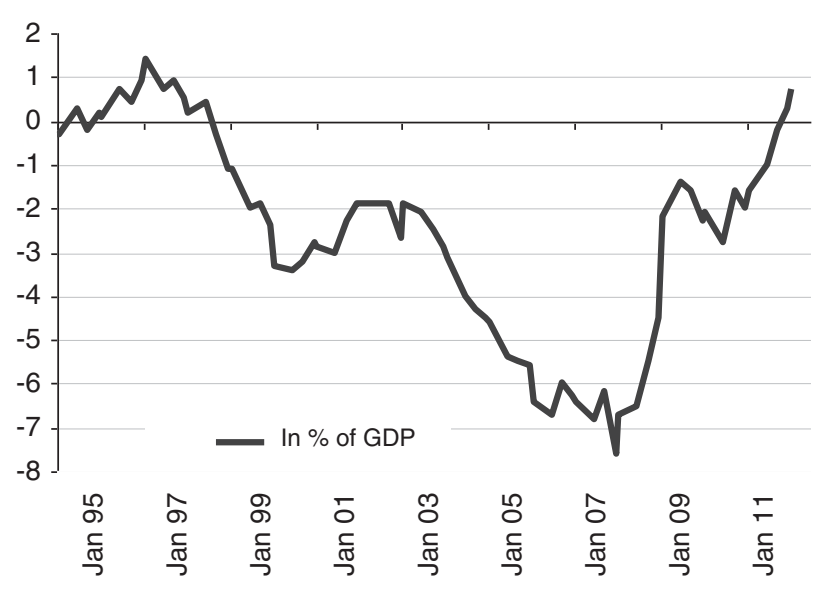

Source: Eurostat

with rules that will make it much more difficult for member countries to live beyond their means in the future.

Chances are that, in one or two years, the Eurozone will be back to trend growth, and enjoying a faster rate of trend growth than before, while the U.S. and U.K. economies could be kept well below their previous rates of trend growth by the need to finally tighten their public finances. After all, the adjustment need in the United States and the United Kingdom is much more pronounced than in the Eurozone.

\section{APPENDIX}

\section{A.1. Case Studies in Eurozone Adjustment ${ }^{2}$}

\section{Germany}

In real life, no country or region can fully conform to the textbook ideal of an "optimum currency area" [Mundell 1961]. The relevant question, then, is whether the Eurozone offers its members adequate opportunities to adjust within the strictures of monetary union. The German example shows that it does. After 2003, Germany turned itself from the "sick man of Europe" [Schmieding 1998] ${ }^{3}$ into the most dynamic of the major European economies. It did so without the ability to set its own interest rates or steer its own exchange rate. This German experience is shaping the German and ECB response to the euro crisis. [2011].

${ }^{2}$ This section draws heavily on Schmieding and others

${ }^{3}$ For a discussion of the longer-run trends in the German economy, see Giersch and others [1992]. 
Over the course of the 1990s, Germany had become the worst-performing of the major European economies. The costs of German unification and the refusal to adjust the generous West German welfare system to the challenge of integrating a bankrupt East German economy with more than 16 million people compounded deep-rooted structural problems. In the wake of a postunification boom-bust cycle, Germany also suffered from a long and painful slump in real estate markets and a protracted banking crisis. When Germany breached the 3 percent deficit limit of the Stability and Growth pact in 2003, it used its political muscle to suspend the pact before teaming up with France to critically dilute it.

Figure A1 shows that in the 1990s, Germany was the only major economy in the Western world blighted by a further trend increase in unemployment. When unemployment soared to new postwar highs in the wake of the 2001-2002 recession, the country finally realised it had a serious problem. It reacted with a thorough overhaul of the German body economic. Specifically, Germany

- slashed welfare, unemployment, pension, and health care benefits;

- made its exceptionally rigid labour market more flexible, for instance by liberalising temporary work contracts;

- reduced top marginal tax rates for households and companies;

- kept increases in discretionary government spending well below the rate of inflation;

- raised indirect taxes to balance the budget.

As unemployment soared, employers also gained the upper hand in negotiations with trade unions. Using the all-toocredible threat of relocating jobs to less costly climes in east-central Europe or East Asia, employers imposed a long period of wage moderation and a significant relaxation of restrictive work practices onto their workers.

Figure A1. German core employment. Core employment: subject to social security contributions

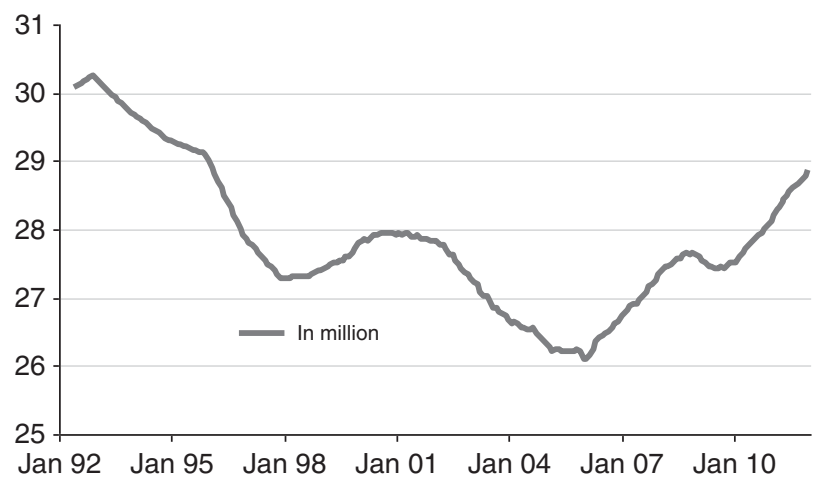

Source: Bundesagentur; Bundesbank.
Germany implemented major labour market reforms in early 2004, as part of the Agenda 2010 reforms. Since then German core employment has expanded by 11 percent, a remarkable achievement at a roughly constant overall population. As a result of a growing number of workers paying into the system, Germany balanced its budget (general government) in 2007 and 2008, returning after the post-Lehman hit to an almost balanced position in 2011 again, with a deficit of a mere 1 percent of its GDP.

The German example holds some key lessons: ${ }^{4}$

- Countries can correct deep-seated domestic distortions within monetary union.

- It can take years for labour market reforms to show clear results.

- But once structural reforms yield results, the economic and fiscal outlook can improve dramatically.

This experience informs the German and the ECB approach to the euro crisis. Both acknowledge that the fiscal repair and structural reforms which countries on the euro periphery have to implement in order to qualify for support are tough. But both are confident that the right mix of austerity and supply-side reforms will eventually lead to stronger supplydriven growth and sustainable public finances.

\section{Greece}

Since the start of its debt crisis, Greece has made a heroic fiscal adjustment. But the Greek story is also one of utter failure. Since the start of its debt crisis in late 2009, the Greek economy has contracted by almost 15 percent.

The deep recession is costing Greece dearly in terms of lost tax revenues and extra expenditure. As a result, the overall fiscal deficit ceased to decline in early 2011 despite further serious fiscal tightening. Even worse, the shrinking GDP automatically boosted the debt-to-GDP ratio. What went wrong in Greece?

At the start of its debt crisis, Greece had some particular strengths and weaknesses. On the positive side, Greece was blessed with:

- a popular and newly elected government with a solid majority in parliament;

- a well-capitalised banking system with a strong deposit base;

- a household and corporate sector with comparatively low debt levels;

- no trace of a real-estate or private sector credit boom that could go or had gone bust.

On the weak side, Greece suffered from

- an exceptional surge in the fiscal deficit in election year 2009 to 15.6 percent of GDP;

${ }^{4}$ See also Schmieding, Holger, Understanding Germany: a last golden decade ahead, Berenberg Bank, October 2010. 
- a collapse of global trust in Greece after it emerged that previous governments had presented inaccurate fiscal statistics;

- a grossly overstaffed and often incompetent public sector;

- a bureaucratic regime that made it exceptionally difficult, expensive, and time-consuming to start a new business;

- a dense network of regulations that closed many professions to newcomers.

The policy advice dished out to Greece had roughly the right ingredients - fiscal austerity and pro-growth structural reforms. But the harsh prescriptions that Greece had to follow to qualify for support got the balance wrong in three major respects:

- Roughly half of the fiscal measures (including the first VAT hike in March 2010) sought to raise more tax revenue instead of reducing government expenditure, although tax increases tend to hit aggregate demand more than spending cuts [International Monetary Fund 2010].

- Instead of simplifying the tax code so that an inefficient tax administration could have better coped with it, the tax code became even more complicated. Frequent tax changes compounded the administrative problem.

- In monitoring Greek progress, donors focussed far more on easily measurable fiscal targets than on progress in the pro-growth structural reforms.

The initial tendency of the EU, ECB, and IMF troika supervising the Greek programme was to react to fiscal shortfalls caused by recession and administrative incompetence by demanding further austerity. This compounded the problems. It deepened the recession and overstretched the very limited administrative capacity of the Greek public sector even further.

A roughly 50:50 mix of tax hikes and expenditure cuts is not unusual in fiscal adjustment programmes. The problem for Greece is that its comparatively closed economy, with a share of exports of merely 25 percent of GDP, translates such a fiscal squeeze into a disproportionate hit to aggregate demand, while its inefficient tax administration limits the fiscal gains from higher tax rates. A key element of success for austerity and reform programmes is to elicit a surge in private sector confidence and investment to offset the fiscal squeeze. But with exceptionally weak domestic demand and tax rates that went up partly to offset deficiencies in tax collection, private investment has been suppressed and driven abroad to friendlier tax climes, such as Bulgaria. Figure A2 shows the ongoing collapse of Greece's domestic economy.

Greece seems to be the classic example of a country with a weak tax administration in which a simple flat tax regime with low but uniform rates could probably have led to a major surge in revenues and private sector activity rather than to a decline in revenues.

On the political side, the focus on short-term fiscal targets rather than longer-term reforms meant that the Greek government spent too much of its political capital on
Figure A2. Greek Industrial Orders. Index Levels, $2000=100$; Three-Month Rolling Average

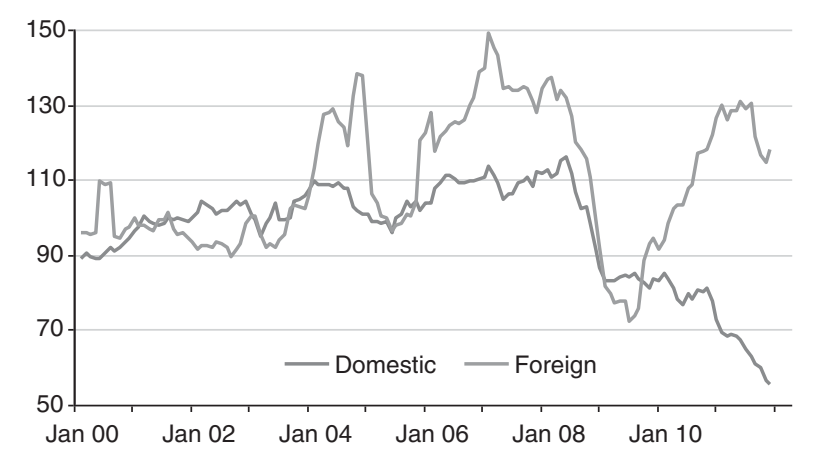

Source: Eurostat.

pushing tax hikes through parliament rather than on loosening regulations and streamlining the public sector. For the outside observer, this partly seemed to reflect the genuine preferences of the Greek government. But given the leverage which the troika has over Greece, the external donors could probably have given the Greek adjustment efforts a different steer if they had insisted on it.

In Greece, the economic problems have been compounded by a loss of confidence that was made worse by the elections on May 6, 2012. Concerned that Greece may potentially have to leave the euro if a new government refuses to accept the bailout terms, Greek businesses have cut their investment expenditures to a bare minimum. Households are also hoarding money (while it is still denominated in euros) to be ready for an even deeper crisis - or to take the money abroad so that it could not be forcibly converted into a weak new national currency.

The current situation has become unsustainable. If Greeks reject the bailout terms wholesale, the flow of support funds from Europe and the IMF will probably cease. This could force Greece to print its own money, as it would be running out of euros. Unlike Argentina, which could simply end the peg to the U.S. dollar, Greece has no national currency. The short-term disruption caused by a possibly chaotic euro exit could be quite significant. But if Greece elects a reform-minded government at the June 17 repeat elections, Europe and the IMF would probably be ready to adjust the current programme for Greece, with a shift of focus away from immediate austerity toward progrowth reforms. If so, the Greek drama could perhaps still have a happy end.

\section{REFERENCES}

Giersch, Herbert, Karl-Heinz Paque, and Holger Schmieding. 1992. The Fading Miracle: 40 Years of Economic Policy in Germany. Oxford University Press. 
International Monetary Fund, 2010. Will it Hurt? Macroeconomic Effects of Fiscal Consolidation. World Economic Outlook.

International Monetary Fund, 2012. Fiscal Monitor: Balancing Fiscal Policy Risks, http://www.imf.org/external/ pubs/ft/fm/2012/01/fmindex.htm.

Mundell, Robert A. 1961. "A Theory of Optimum Currency Areas." American Economic Review, 41(4): 657-65.
Schmieding, Holger. 1998. "Germany: The Sick Man of Europe?" European Monitor, Merrill Lynch.

Schmieding, Holger, Paul Hofheinz, Jörn Quitzau, Anja Rossen, and Christian Schulz. 2011. The 2011 Euro Plus Monitor: Progress Amid the Turmoil, Berenberg Bank and the Lisbon Council. November 15, http:// www.lisboncouncil.net/publication/publication/68-the2011-euro-plus-monitor.html. 